\title{
Emotional Intelligence Quotient and Leadership Effectiveness in the Pharmaceutical Industry: A New Template
}

\author{
Z. Kasapi ${ }^{1} \&$ A. Mihiotis ${ }^{1}$ \\ ${ }^{1}$ School of Social Sciences, Hellenic Open University, Patras, Greece \\ Correspondence: A. Mihiotis, School of Social Sciences, Hellenic Open University, 57-59 Bouboulinas Str., 26222 \\ Patras, Greece. E-mail: mihiotis@eap.gr
}

Received: October 25, 2013

Accepted: November 27, $2013 \quad$ Online Published: January 11, 2014

doi:10.5430/ijba.v5n1p15

URL: http://dx.doi.org/10.5430/ijba.v5n1p15

\begin{abstract}
Emotional Intelligence reflects the ability to feel and understand other people in social situations, to detect the nuances of emotional reactions and to utilize such knowledge to influence others through emotional regulation and control. As a result, it represents a critically important competency for effective leadership and team performance in organizations in the existing crisis era. In this paper, based on the international bibliography, we are trying to develop a Theoretical Communication Model on emotional intelligence and leadership effectiveness so as to be applied in the decision making process for middle and senior managers of the Pharmaceutical Industry.
\end{abstract}

Keywords: emotional intelligence, leadership effectiveness, theoretical communication model, pharmaceutical industry

\section{Introduction}

What we refer to as Emotional intelligence is most commonly addressed as the individual's capability to highly perceive own personal emotions and those of others and be able to "handle" those emotions by interacting with all audiences forming relationships i.e business relationships, personal relationships etc. Emotional intelligence suggests four very important competencies: (1) Self- awareness, which is the competency to strongly understand one's emotions and be conscious of them as they happen, basically by managing one's reaction to certain situations and people. (2) Self-management, which is the competency to stay alert of one's emotions and be flexible to drive positively his/hers behavior towards those emotions, and be able to address all possible emotional reactions for all situations and for all people. (3) Social awareness, which is the competency to correctly recognize emotions of others and their possible effects, i.e., to be able understand other people's thoughts and sense their feelings even though they do not correspond quite like this. (4) Relationship management, which is the competency to successfully manage interactions by using own efficient levels of awareness for one's own emotions and those of others i.e., provide clear communication to all involved and effectively handle conflict (Bradberry \& Greaves, 2003).

According to Harms and Credé (2010), emotional intelligence is regarded as either a trait or an ability. In the first case, emotional intelligence is viewed as an inherent considered being an innate feature that enables and promotes well-being. In the second case, emotional intelligence plays a role in comprehending and regulating emotions as well as in understanding and integrating them into cognitions. This debate on the status of emotional intelligence has led Mikolajczak et al. (2009) to suggest a tripartite model of emotional intelligence, in which three levels of emotional intelligence are introduced: knowledge (what people know about emotions and how to deal with emotion-laden situations), abilities (what people can do) and traits (what people actually do). Several scientific investigations have measured the effects of emotional intelligence on significant outcomes, such as life quality, occupational success, resistance to stress etc. (Nelis et al., 2009). However, up to recent time, emotional intelligence was perceived as a field applying mainly on leadership and performance, but with little touch on the broad field of organizational behavior. In fact little could be found on how emotional intelligence is related to social interaction processes. Few studies, as yet, have clearly stated emotional intelligence as a moderator of these processes and resulting outcomes (Douglas, Frink, \& Ferris, 2004). Emotional labor is a social interaction process which displays emotion clearly as a requisite to performance. It would appear that the main attributes of emotional intelligence are directly related to the attributes and requirements of the actual emotional labor process. Definitional comparison of the concepts has shown this to be readily apparent. The qualities of emotional intelligence are important to practice emotional labor effectively. In 
addition, emotional intelligence is key to manage levels of stress which is common in emotional labor practices. In fact there are few studies that have measured the impact of emotional intelligence on reducing stressors such as emotional labor and resulting strains (Ciarrochi, Deane, \& Anderson, 2002; Slaski \& Cartwright, 2002). Emotional intelligence has proven particularly important in the service sector and in instances where employees interact with customers (Sy et al., 2006; Bono et al., 2007). Leaders high on emotional intelligence are rather better at helping their employees keep positive moods while interacting with customers and performing emotional labor (O'Boyle Jr et al., 2010).

Taking into consideration the very great importance of understanding one's feelings in accordance to other persons' emotions in order to be applied to maximize communication and leadership effectiveness for productivity \& profitability's sake via the business plan's implementation, this particular review seems to become a necessary tool for middle and senior level managers who need to improve their own \& subordinates' EQ status, as well. More specifically, the development of a particular Theoretical Communication Model that is based on the axis of EQ, leadership \& decision making process will result in the enhancement of Sales and Marketing Departments that constitute the most important parts of a pharmaceutical/commercial company.

\section{Relationship between EI \& Effective Leadership Skills}

Mastering the skills in the areas of self-awareness, self-management, social awareness, and relationship management can translate into success in the workplace. Goleman asserts that a person's ability to perceive, identify and manage emotions can reflect social and emotional competencies that are essential for success in the workplace (Goleman, 1998, 2001). In time the importance of Emotional Intelligence Quotient (EQ) has grown as relationships and communication have become core functions within organizations and business entities, along with intelligence and technical skills. This has moved the action to further look into the nature of EQ. For Mayer, emotional intelligence is the ability to understand how others' emotions work and to control one's own emotions. Goleman, on the other hand, examining the importance of EQ in every people-oriented position, defines emotional intelligence more broadly, suggesting terms like optimism, conscientiousness, motivation, empathy, and social competence.

In "Working with Emotional Intelligence," Goleman (1998) suggests that the most important factor which determines successful leaders is their Emotional Intelligence Quotient (EQ) rather than their IQ. Goleman also demonstrated that emotional intelligence is the one critical factor for personal adjustment, success in relationships, and job performance. He argued that IQ counts only for the little 20 percent of success, whereas EQ is responsible for the remaining enormous 80 percent. Based on emotional intelligence, managers can hold back on their anger, self-doubt, and are able to manage effectively all other rather negative feelings. It provides great support and makes them focus on the rather positive emotions such as confidence and congeniality. Most of all it is accepted that EQ can be learnt, improved, trained, and matured whereas unfortunately IQ is granted. Furthermore, Goleman's book, Social Intelligence (2006) makes the case for the "social brain" that is wired to connect with other brains and thereby mold both our experience and our neural circuitry. Goleman asserts, "The brain-to-brain link allows our strongest relationships to shape us on matters as benign as whether we laugh at the same jokes or as profound as which genes are (or are not) activated in T-cells, the immune system's foot soldiers in the constant battle against invading bacteria and viruses" (Goleman, 2006). Bradford's analysis (1984), argues that a successful leader not only is capable of motivating, controlling, and coordinating his associates but also involves them actively into the decision making process. His effectiveness is related deeply with his capacity and ability to drive, but also motivation, honesty/integrity, self-confidence, intelligence, and levels of emotional intelligence, all of which can be developed through experience, training, and analysis. Such learning process involves on going training and supports managers to understand themselves and others, understand the emotional portraits of others and the implication of these portraits for work performance. It supports effort to build EQ for themselves and others, and effectively relate to broad audiences. Cooper and Sawaf (1997) also demonstrated the impact of emotional intelligence regarding levels of success for a personal career or organizational growth, since it comes in terms with motivation, information, feedback, personal power, innovation, and influence "Executive EQ".

Besides, based on the Bar-on model of Emotional and Social Intelligence (2006), one must examine the impact of age, gender, and ethnicity on EQ-inventory which is mentioned as a valuable means and tool of measuring emotional intelligence. Furthermore EI measures have proved of high internal consistency reliability. Self-report EI measures as well as the overall scales for ability-based measures have acceptable internal consistency. Nevertheless, this data provides with no clear signal on whether EI results are simply assessing constructs already extracted by other, or they are more established constructs.

A relevant few of the subscales for the ability-based EI measures come with initially acceptable internal consistency and test-retest adequacy. One cannot tell for certain if EI measures are valid or reliable. Validation of content for EI 
measures is subject to vague theoretical development for many of the measures as the content itself varies widely. The case is that it is difficult to examine content validity because very few EI researchers are specific about what they want to measure. Also, these measures lack convergent and discriminant validity. They have failed to converge on a common construct, they also appear to involve existing personality characteristics or perhaps emotional competencies, whereas they do not appear to assess intelligence (Mayer, Caruso, \& Salovey, 2000). Besides, all of the EI measures face with some serious concerns, which have to do with scoring and validation because of discriminant factors affecting both processes. The ability-based EI measures may in fact appear to be the most promising, but there are numerous untouched issues regarding them as well. Gowing (2001) suggests that besides the fact that most EI measures have been used for development, there is a trend to use them for the selection process as well.

Managers and other organizational decision-makers should be careful when they make this leap and hold back for more advanced, predictive and incremental validity evidence for EI measures. Despite the fact that Mayer et al. (2003) are the makers of the most efficient and promising EI tests, they suggest that 'the applied use of EI tests must proceed with great caution'.

EI supports the whole decision making process, leadership effectiveness, strategic and technical outcomes, open honest communication, trusting relationships and teamwork, customer loyalty, and creativity/innovation. It helps managers to accept and understand feelings of themselves and others, and enables them to interact effectively with great response time. EI also contributes greatly into positive results for one's work and everyday routine. High level of self- awareness together with EQ makes leaders show self-confidence and acquire respect and trust from associates. They can objectively consider needs of others via self-control, despite their own immediate feelings. Leaders which are able to achieve balance, high levels of self-motivation, being optimistic and hopeful, consequently are positive role-models that help others to follow on their track. The skill to empathize with others and to interact positively also contributes to motivate and inspire team members. EQ enables leaders to recognize and respect associates with feelings, listen to their opinions and ideas, but most important manage them as persons with unique needs and abilities. Empathic leaders make all actions to assist their associates to further develop and enhance their skills and achieve their goals.

Many of the EI features are intertwined with those of leadership to the extent that many researchers state that these two aspects are strongly interrelated. In fact, some researches revealed that outstanding leaders have 15\% IQ and technical skills, and 85\% EI (Goleman, 1998).Bliss (2005) and Besterfield et al. (2003) have explored the strength of this relationship by considering the characteristics of leaders. Based on the traits that leaders share, they are considered to be people who look to the horizon and strive to change the current paradigm, from different perspectives than those considered by their followers. They are visionary people who are considered "Quality leaders" because they seek to achieve total quality in the organization, starting with their own personalities and traits. Studies by Sosik and Megerian (1999) indicated that EI constitutes the basis for many of leadership characteristics. It contributes to the effectiveness of leaders by giving them the ability of being aware of themselves and others (Luthans, 2002). For example, Robbins and Judge (2012) contend that a core component of EI is empathy. Empathetic leaders can sense others' needs, listen to what followers say, and read the reactions of others. Moreover, Champy (2003) noted that "the caring part of empathy, especially for the people with whom you work, is what inspires people to stay with a leader when the going gets rough. The mere fact that someone cares is more often than not rewarded with loyalty".

Eventually, having highly effective leaders in an organization is, in addition to their possession of basic leadership skills, one of the main keys in managing human resources; especially, on team- basis projects (Schwalbe, 2001).Freedman and Everett (2004) reported in their research that the Harvard Business Review (2003) had reminded leaders that their excellence begins and ends with their inner resources: "Executives who fail to develop self-awareness risk falling into an emotionally deadening routine that threatens their true selves. Indeed a reluctance to explore your inner landscape not only weakens your own motivation but can also corrode your ability to inspire others." Moreover, Bar On and Orme (2003) in a study of one of the UK's largest restaurant groups found that there was clear evidence that emotionally intelligent leaders were more effective in what they do. Managers high in emotional intelligence had restaurants that outperformed others: increased guest satisfaction, lower turnover, and 34\% greater profit growth. Furthermore, according to McClelland (1998), the link between EQ and leadership was also clear at PepsiCo. In a pilot project, executives selected for their EQ competencies far outperformed their colleagues, delivering: (i) $10 \%$ increase in productivity, (ii) $87 \%$ decrease in executive turnover ( $\$ 4 \mathrm{~m}$ ), (iii) $\$ 3.75 \mathrm{~m}$ added economic value and (iv) over $1000 \%$ return on investment.

Also, as the concept of "Quality Leadership" starts from the personality of the leaders themselves, "Emotional Intelligence" concept is based on the fact that leaders cannot but bring their own behaviors and attitudes to the 
workplace. Thereby, their effect on employees is not only related to job characteristics, but also to the ethical and behavioral standards that leaders hold. In other words, both the domains of Emotional Intelligence and the habits and characteristics of effective leaders, interact with each other in a way that would eventually lead to the improvement of work relations between management and employees.

Furthermore, to enhance added value of emotional intelligence in leadership, recent studies suggest that we come across higher EI levels among workplace leaders, which get even higher as leadership scales are higher within an organization (Dulewicz \& Higgs, 2003). Freshman and Rubino (2002), suggest that the consulting firm Hay/McBer has produced research on executive leadership styles based on the key components of emotional intelligence. Dulewicz and Higgs (2000) proved that emotional intelligence could be more important than intellect and other management attributes competencies, after a seven-year long-lasting research. Emotional intelligence (EI) theory a unified framework to study the role of emotional abilities in social functioning (Salovey \& Mayer, 1990). Deeter-Schmelz, Goebel, and Norman (2008), argue that high levels of emotional intelligence are in position to change an efficient sales manager into an exceptional leader. It is a fact that it would be to great benefit for people involved in leadership to be able with EI to drive all positive emotions towards max performance and navigate negative emotions so as to turn them into challenging objectives in leadership (Law, Wong \& Song, 2004). Dulewicz and Higgs (2000) argue that leaders which have a well balanced mix of IQ and EI levels prove to be more successful from those that do not.

According to Daniel Goleman's theory (1998), there are five main elements of emotional intelligence: 1. Self-awareness, 2. Self-regulation. 3. Motivation. 4. Empathy.5. Social skills. The more a leader can manage each of these areas, the higher his/her emotional intelligence is. So, let's look at each element in more detail and examine how one can grow as a leader.

1). If one is self-aware, he always knows how he feels. And one knows how his emotions and actions can affect the people around him. Being self-aware when he's in a leadership position also means having a clear picture of his strengths and weaknesses. And this means having humility. So, what can he do to improve his self-awareness?

- To keep a journal - Journals help improve one's self-awareness. If one spends just a few minutes each day writing down one's thoughts, this can move him to a higher degree of self-awareness.

- To slow down - When he experiences anger or other strong emotions, he must slow down to examine why. He has to remember, no matter what is the situation that he can always choose how he reacts to it.

2). Leaders who are in position to manage themselves effectively are seldom offensive, furious in decision making process, and not loyal to their values. Self- control and self -management is the key stay in the drivers' seat. This competency of emotional intelligence, also implies a leader's flexibility and engagement to personal accountability (Goleman, 1998). So, how can one improve one's ability to self-regulate?

- To know his values - Does he have a clear idea of where he absolutely will not compromise? Does he know what values are most important to him? He must spend some time examining his "code of ethics." If he knows what's most important to him, then he probably won't have to think twice when he faces a moral or ethical decision - he'll make the right choice.

- To hold oneself accountable - If he tends to blame others when something goes wrong, stop. He must make a commitment to admit his mistakes and face the consequences, whatever they are. He'll probably sleep better at night, and he'll quickly earn the respect of those around him.

- To practice being calm - The next time he's in a challenging situation, be very aware of how he acts. He must try to write down all of the negative things he wants to say, and then rip it up and throw it away. Expressing these emotions on paper (and not showing them to anyone!) is better than speaking them aloud to his team.

3). Self-motivated leaders consistently work toward their goals. And they have extremely high standards for the quality of their work. How can one improve one's motivation?

- To re-examine why he's doing this - It's easy to forget what he really loves about his career. So, he must take some time to remember why he wanted this job. And he must make sure that his goal statements are fresh and energizing.

-To know where he stands - He must determine how motivated he is to lead.

-To be hopeful and find something good - Motivated leaders are usually optimistic, no matter what they face. Adopting this mindset he might take practice. Every time he faces a challenge, or even a failure, he must try to find at least one good thing about the situation. 
4). Empathy is very crucial for leaders, that are expected to manage teams succesfully as they tend to put themselves in others' roles. They are great listeners and excellent targets' setters making the best in assisting team members further enhance their skills and abilities. They are honest and fair when challenging others and always provide constructive feedback. How can one improve one's empathy?

- To put oneself in someone else's position - It's easy to support one's own point of view. After all, it's his! But he must take the time to look at situations from other people's perspectives.

- To pay attention to body language - Perhaps when he listens to someone, he crosses his arms, moves his feet back and forth, or bites his lip. This body language tells others how he really feels about a situation, and the message he's giving isn't positive! Learning to read body language can be a real asset when he's in a leadership role because he'll be better able to determine how someone truly feels. And this gives him the opportunity to respond appropriately.

- To respond to feelings - You ask your assistant to work late - again. And although he agrees, you can hear the disappointment in his voice. So, respond by addressing his feelings. Tell him you appreciate how willing he is to work extra hours, and that you're just as frustrated about working late. If possible, figure out a way for future late nights to be less of an issue (for example, give him Monday mornings off).

5). Leaders which are socially highly efficient prove to be excellent communicators. They are always up to new things, never hesitate to face bad news from team and always make everyone highly committed to achieve targets. Leaders with adequate social skills are excellent diplomats and manage change most efficiently as they rarely leave things where they stand. They lead by example performing great behavior to others. Is there a way to improve your leadership style by developing social skills?

-To adopt conflict resolution - Leaders have to be in position to manage conflicts and arguments within their teams and all involved business partners, i.e customers, vendors. Adopting conflict resolution skills is a crucial factor affecting results and success.

- To enhance their communication skills - How efficient do they communicate?

- Learn how to praise others - Being a successful leader requires to be in position to praise effort and determination before result so as to stand by and continuously motivate. Praise others is true virtue for leaders.

\section{Pharmaceutical Industry Definition \& Characteristics}

As per the discussion of this study, the pharmaceutical industry develops, produces, and markets drugs licensed for use as medications (McGuire, 2007). Pharmaceutical companies can deal in generic and/or brand medications. They are subject to a variety of laws and regulations regarding the patenting, testing and marketing of drugs.

Most of today's major pharmaceutical companies were founded in the late 19th and early 20th centuries. Key discoveries of the 1920s and 1930s, such as insulin and penicillin, became mass-manufactured and distributed. Switzerland, Germany and Italy had particularly strong industries, with the UK, US, Belgium and the Netherlands following suit. The pharmaceutical industry entered the 1980s pressured by economics and a host of new regulations, both safety and environmental, but also transformed by new DNA chemistries and new technologies for analysis and computation. It has also confronted a new business climate and new regulations, born in part from dealing with world market forces and protests by activists in developing countries.

As far as the world pharmaceutical industry concerned, one may define some main characteristics as follows:

- increased globalization,

- changing structure of competition and increased competitiveness,

- lack of new products, despite increased investments into R\&D (Research \& Development) activities,

- fast consolidation and concentration of the world pharmaceutical industry,

- increased importance of strategic management,

- $\quad$ increased importance of leadership effectiveness \& EQ management,

- development of new therapeutic fields and technologies (biotechnology, pharmacy genomics),

- ageing of world population and opening up of new, not yet satisfactorily covered therapeutic fields,

- $\quad$ quick development of the world generic markets (Kasapi \& Mihiotis , 2011).

Taking into consideration the fact that the pharmaceutical business world is becoming increasingly global, cultural differences consist a very important factor. Business success and high performance depend heavily on the quality of effective multinational corporate leadership (Adler, 2002). Gregersen, Morrison, and Black (1998) conducted a study which showed that 85 percent of the U.S Fortune 500 firms do not believe that they employ a solid number of true 
global leaders to secure their position and drive business forward. Furthermore, management and leadership style are highly affected by a nation's specific cultural attributes. As Leung (2005) argued that effective leadership in one cultural environment may be ineffective by studying the example of Western managers in Chinese firms. It is a fact, that organizations become more effective when they are in place to identify and acquire the necessary leader behaviors applied to the existing cultural situation. For example in countries with a strict time management policy i.e meetings or deadlines , managers are expected to be always on time, while for countries like Greece or Italy that deadlines are not so important things may be different in evaluating managers' behavior and performance. (Trompenaars, 1993). There are cultures, for example India, that focus on long term performance reward and career development whereas there are cultures like United States that $d$ focus on short-term recognition and reward (Ilangovan, Scroggins, \& Rozell, 2007). Thus, it is very important for someone who is a leader or a manager in a diverse environment to be able to adopt to cultural differences and bring together different styles and attributes to form his strategy for success (Adler, 2002). A truly experienced manager will have to know how to use EI competencies to drive the organization forward and achieve challenging targets without neglecting specific cultural attributes. Research on the effect of national cultures to organizational cultures have shown that local cultures are highly influential to business environments (Hofstede, 1997; Adler, 2002), and in addition we come across greater differences in organizational attributes and practices when we face great cultural distance between the two countries, (Javidan \& House, 2002). Due to all these special features and factors along with the pharmaceutical companies, a leader must also apply the strategies of pharmaceutical marketing, because they are characterized as the main functional strategies of the business (Kazazis, 2011). Additionally, they are closely connected with the other functions of management (financial, production etc) together with the corporate strategy and the business strategy, as well. Pharmaceutical marketing' strategies also includes decision planning associated with the distribution of business' resources in order to obtain competitive advantage in the targeted markets (Mihiotis, 2005).

\section{Objectives and Methodology}

As it has already been said, Emotional Intelligence Quotient is defined as a set of competencies demonstrating the ability one has to recognize his or her behaviors, moods, and impulses, and to manage them best according to the situation. Furthermore, "It is important for entrepreneurs to have a high emotional intelligence quotient to succeed in business. Emotional intelligence refers to the ability to relate with people and understand their emotions. This quality is essential in managing employees, getting customers and attracting investors" (McGarvey, 1997). Studies worldwide show, across all job types, that EQ is the strongest predictor of the job success.

Based on the literature briefly described above, it is suggested that feelings serve multiple purposes in human affairs and play an important role in leadership. George and Bettenhausen (1990) and George (1995) looked into the beneficial results of a leader's positive attitude, whereas we can also argue that a complex of feelings (both emotions and attitudes) affects leadership efficiency. For example, negative attitudes, lead to thorough situation analysis and evaluation of available information (Sinclair, 1988; Sinclair \& Mark, 1992) and favor leaders who manage problems to evaluate high risk in the decision making process. They may also increase spontaneous awareness and levels of attention to immediate take action on issues occurred (Frigda, 1988).

As a matter of fact, leaders may follow more effective methodologies and techniques in order for them to be able to change their negative moods and feelings to develop alternative solutions to interpersonal, job, financial and other problems (McKay, 2007). By now, it may be apparent that it is not too difficult to construct scenarios in which leaders would be well served by the experience of a variety of types of moods and emotions. Moreover, one can also construct scenarios in which a leader's effectiveness may be hampered by the experience of certain moods and emotions. Leaders who experience anger frequently may have a difficult time building good relationships with followers and engendering their trust (Jones \& George, 1998).

Whenever one experiences anger, there is a thought connected to it which helps define that mood. Thoughts help define which mood we experience in a given situation. Once a mood is present, it is accompanied by additional thoughts that support and strengthen the moods. For example, angry people think about ways they have been hurt, depressed people think about how unfortunate life has become and anxious people see danger everywhere. Similarly, a leader who frequently experiences positive moods on the job may fail to notice and attend to performance shortfalls that are less than apparent (Greenberger, 1995). For instance, Coca-Cola saw division leaders who developed EQ competencies outperform their targets by more than $15 \%$. Division leaders who didn't develop their EQ missed targets by the same margin (McClelland, 1999). Additionally, L'Oreal realized \$91,370 increase per head for salespeople selected for EQ skills. The group also had 63\% less turnover than sales staff not part of the EQ program (Cherniss, 2003). At Sanofi-Aventis, a pharmaceutical company, a group of salespeople was randomly split into a control and development group. The development group received emotional intelligence training and increased their EQ by $18 \%$ (on average), after which they out-sold the control group by an average of $12 \%$, or $\$ 55,200$ each $\times 40$ reps $=2,208,000.00$ per month better. The company calculated that they made $\$ 6$ for every dollar they invested in the training. 
As a matter of fact, by reviewing international bibliography, this particular investigation's purpose can be defined firstly by finding out if pharmaceutical companies are aware of EQ's important role on business success, secondly by cultivating/ developing their employees' skills through training programs so as to enhance their managers' emotional sensitivity to be engaged in the six strategies for increasing EQ proposed by Weisinger (1998) ; and additionally by searching how middle and high level managers communicate with their subordinates while affected by EQ's principles \& leaderships styles as useful tools - in order for them to be able to increase their performance and therefore company's productivity, by applying the most appropriate decision making process and leadership effectiveness, as proposed by Walumbwa (2011).

To manage the above mentioned purpose, this particular research will deal with the creation of a theoretical communication model -derived by the international bibliography- having as target population of the study, supervisors, middle managers, and seniors in pharmaceutical organizations to extract \& elaborate the following data:

- The identification and management of EQ factor among the subjects, which include self-awareness, self-regulation, self-motivation, empathy, social skills

- The identification of which EQ characteristics most explain communication competences \& leadership effectiveness

- The identification of what extent the EQ characteristics contribute to communication \& leadership effectiveness

- The assessment of the relationship between EQ characteristics and decision making process to improve communication \& leadership effectiveness

- The assessment of the relationship between EQ factors and organizations' goals' attainment (Pieterse, 2011) in the context of the existing crisis management era.

In practice, the success of this research's aim is based on the above mentioned theoretical communication model which includes the necessity of existence \& use of all EQ characteristics in pharmaceutical business as important factors in leadership, decision making processes together with the ultimate motivation of subordinates that plays the most important role in companies' goals attainment. It is important in order for leaders to identify EQ characteristics in themselves \& their subordinated employees, as well, to make use of the following Emotion Log (Figure 1) so as to write down their own feelings/reactions together with other people's ones, too.

\begin{tabular}{|c|c|c|c|c|c|}
\hline Emotion & Monday & Tuesday & Wednesday & Thursday & Friday \\
\hline \multicolumn{6}{|l|}{ Happiness } \\
\hline \multicolumn{6}{|l|}{ Affection } \\
\hline \multicolumn{6}{|l|}{ Interest } \\
\hline \multicolumn{6}{|l|}{ Excitement } \\
\hline \multicolumn{6}{|l|}{ Pride } \\
\hline \multicolumn{6}{|l|}{ Desire } \\
\hline \multicolumn{6}{|l|}{ Love } \\
\hline \multicolumn{6}{|l|}{ Loved } \\
\hline \multicolumn{6}{|c|}{ Thankfulness } \\
\hline \multicolumn{6}{|c|}{ Stress } \\
\hline \multicolumn{6}{|l|}{ Hurt } \\
\hline \multicolumn{6}{|l|}{ Sadness } \\
\hline \multicolumn{6}{|l|}{ Irritation } \\
\hline \multicolumn{6}{|l|}{ Anger } \\
\hline \multicolumn{6}{|l|}{ Pity } \\
\hline \multicolumn{6}{|l|}{ Disgust } \\
\hline \multicolumn{6}{|l|}{ Guilt } \\
\hline \multicolumn{6}{|l|}{ Envy } \\
\hline \multicolumn{6}{|l|}{ Regret } \\
\hline Shame & & & & & \\
\hline
\end{tabular}

Figure 1. Emotion log (Adapted from www.visionrealization.com/Randall Grayson) 
Further to the completion of the above-mentioned Emotion Log and based on Mayer Salovey's Four Branch Ability Model (1997), one has to make some important steps as follows:

- Reflective Regulation of Emotion to Promote Emotional and Intellectual Growth

- Understanding and Analyzing Emotions; Employing Emotional Knowledge

- Emotional Facilitation of Thinking

- Perception, Appraisal and Expression of Emotion

More analytically, Reflective Regulation of Emotion to Promote Emotional and Intellectual Growth has to do with: (a) The ability to stay open to feelings, both those that are pleasant and those that are unpleasant, (b) The ability to reflectively engage or detach from an emotion depending upon its judged informativeness or utility, (c) The ability to reflectively monitor emotions in relation to oneself and others, such as recognizing how clear, typical, influential or reasonable they are, (d) The ability to manage emotion in oneself and others by moderating negative emotions and enhancing pleasant ones, without repressing or exaggerating information they may convey.

Understanding and Analyzing Emotions; Employing Emotional Knowledge is derived from: (a) The ability to label emotions and recognize relations among the words and the emotions themselves, such as the relation between liking and loving, (b) The ability to interpret the meanings that emotions convey regarding relationships, such as that sadness often accompanies a loss, (c) The ability to understand complex feelings: simultaneous feelings of love and hate or blends such as awe as a combination of fear and surprise, (d) The ability to recognize likely transitions among emotions, such as the transition from anger to satisfaction or from anger to shame.

Perception, Appraisal and Expression of Emotion has to do with: (a) The ability to identify emotion in one's physical states, feelings, and thoughts, (b) The ability to identify emotions in other people, designs, artwork, etc. through language, sound, appearance, and behavior, (c) The ability to express emotions accurately, and to express needs related to those feelings, (d) The ability to discriminate between accurate and inaccurate, or honest vs. dishonest expressions of feeling.

Emotional Facilitation of Thinking is associated with: (a) Emotions prioritize thinking by directing attention to important information, (b) Emotions are sufficiently vivid and available that they can be generated as aids to judgment and memory concerning feelings, (c) Emotional mood swings change the individual's perspective from optimistic to pessimistic, encouraging consideration of multiple points of view, (d) Emotional states differentially encourage specific problem-solving approaches such as when happiness facilitates inductive reasoning and creativity.

A depiction of this four-branch model is illustrated in Figure 2, which outlines the four branches and the corresponding stages in emotion processing associated with each branch.

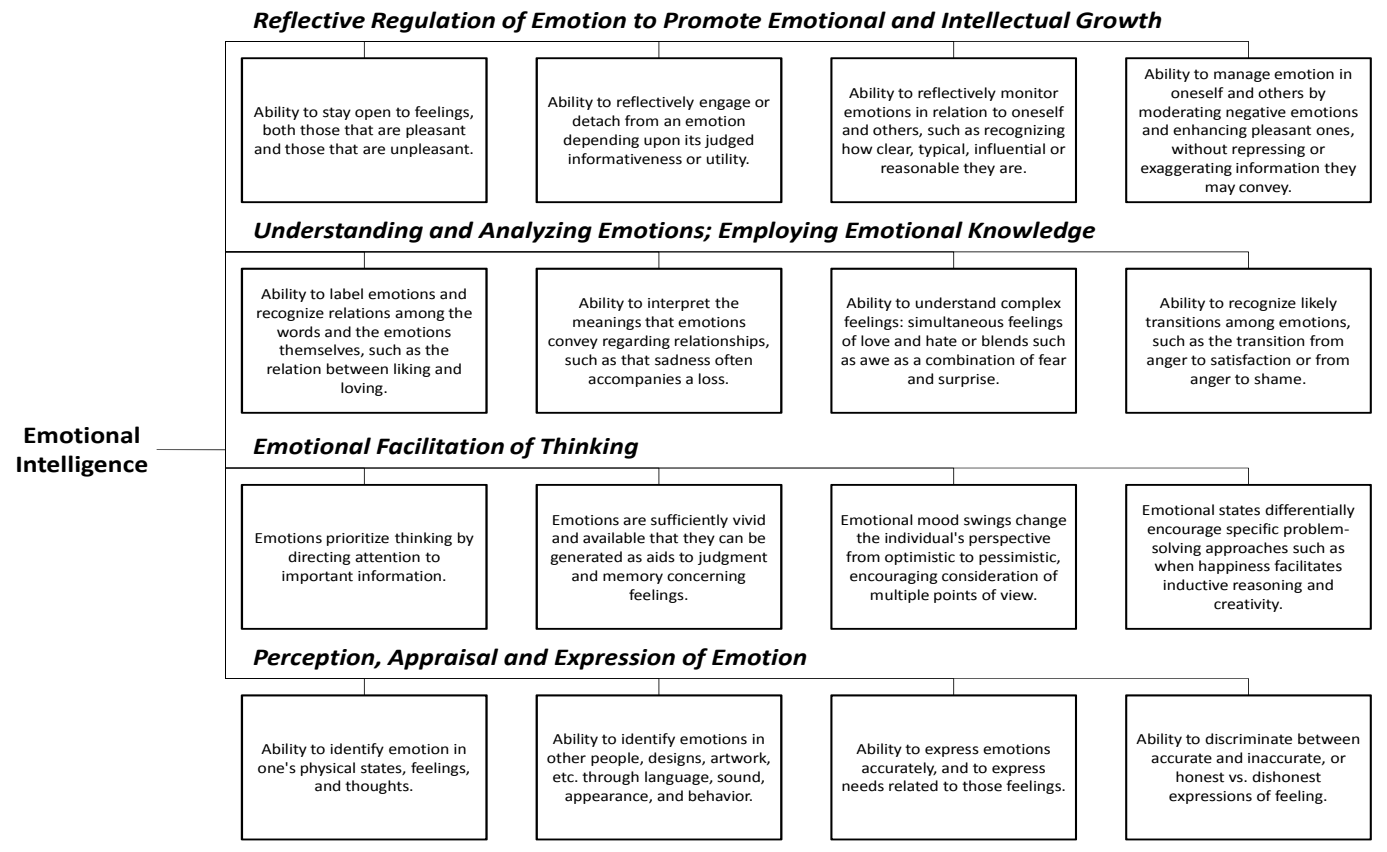

Figure 2. Mayer and Salovey's (1997) four-branch model of emotional intelligence 
On the other hand and based on Mixed Models that treat mental abilities and a variety of other characteristics such as motivation, states of consciousness and social activity as a single entity (Bar-On, 1997b), one has to make some important steps as follows:

- Intrapersonal Skills

- Interpersonal Skills

- Adaptability Scales

- Stress-management Scales

- General Mood

More specifically, Intrapersonal Skills have to do with: (a) Emotional self-awareness, (b) Assertiveness, (c) Self-Regard, (d) Self-Actualization, (e) Independence.

Interpersonal Skills are associated with: (a) Interpersonal relationships, (b) Social Responsibility, (c) Empathy. Adaptability Scales have to do with: (a) Problem Solving, (b) Reality testing, (c) Flexibility.

Stress- management Scales have to do with: (a) Stress tolerance, (b) Impulse control

General Mood is associated with: (a) Happiness, (b) Optimism

Moreover and based on Mixed Models (Goleman, 1995a), a senior manager in the pharmaceutical sector has to make some more important steps as follows:

- Knowing one's emotions

- Managing emotions

- Motivating oneself

- Recognizing emotions in others

- Handling Relationships

More analytically, Knowing one's emotions has to do with: (a) Recognizing a feeling as it happens, (b) Monitoring feelings from moment to moment.

Managing emotions is associated with: (a) Handling feelings so they are appropriate, (b) Ability to soothe oneself, (c) Ability to get rid of anxiety or irritability

Motivating oneself has to do with: (a) Marshaling emotions in the service of a goal, (b) Delaying gratification \& stifling impulsiveness, (c) Being able to get into the "flow" state.

Recognizing emotions in others has to do with: (a) Empathic awareness, (b) Attunement to what others need or want. Handling relationships is associated with: (a) Skill in managing emotions in others, (b) Interacting smoothly with others.

Figure 3 illustrates Goleman's conceptual model of emotional intelligence and corresponding emotional competencies. The constructs and competencies fall under one of four categories: the recognition of emotions in oneself or others and the regulation of emotion in oneself or others.

\begin{tabular}{ccc}
\cline { 2 - 3 } & $\begin{array}{c}\text { SELF } \\
\text { Personal Competence }\end{array}$ & $\begin{array}{c}\text { OTHER } \\
\text { Social Competence }\end{array}$ \\
\hline \multirow{2}{*}{ RECOGNITION } & Self-Awareness & $\frac{\text { Social Awareness }}{\text { Empathy }}$ \\
& $\begin{array}{c}\text { Emotional self-Awareness } \\
\text { Accurate self-Assessment } \\
\text { Self-Confidence }\end{array}$ & $\begin{array}{c}\text { Service Orientation } \\
\text { Organizational Awareness }\end{array}$ \\
\hline \multirow{2}{*}{ REGULATION } & Relationship Management \\
& Self-Management & Developing Others \\
& Trustworthiness & Influence \\
& Conscientiousness & Communication \\
& Adaptability & Conflict Management \\
& Achievement Drive & Leadership \\
& Initiative & Change Catalyst \\
& & Building Bonds \\
& & Teamwork and Collaboration \\
\hline
\end{tabular}

Figure 3. Goleman's (2001) emotional intelligence competencies 


\section{Epilogue}

It is more than 20 years that emotional intelligence placed itself within the interests of the academic community, business entities and people audiences in general. Today we come across three different models of emotional intelligence all of which come along with their own measurement processes. The very first of models focuses on cognitive ability and sets itself with an outcome of performance-based measure of E.I. The other two are mixed models which both stretch both cognitive ability and personality traits use self-report measures.

By searching global bibliography, we can assume that no specific study has been carried out for EQ influence and application to the pharmaceutical sector, as a result this particular research is intended to be an appropriate tool available for all pharmaceutical companies' executives since it deals with the usefulness and application of EQ incorporated in the communication model of leadership effectiveness, decision making process that are associated with productivity and general professional success in everyday's life practice.

Besides, additional research is needed to gain not only theoretical consensus but also clarity regarding the most appropriate measurement strategy among E.I., leadership effectiveness and decision making process.

Finally, it is recommended that the relationship among EQ / communication model and leadership / organizations' decision making process has to be studied in other industries and professions so as for the researchers to be able to extract comparable conclusions.

\section{References}

Adler, Nancy J. (2002). International Dimensions of Organizational Behavior (4th ed.). Cincinnati: South-Western/Thomson Learning.

Bar On, R., \& Orme, Geetu. (2003). In Orme and Langhorn, Lessons learned from implementing EI programs - the cutting edge of emotional intelligence interventions. Competency \& Emotional Intelligence Quarterly, 10(2), 32-39.

Bar-On, R. (1997b). The Emotional Quotient Inventory (EQ-i): Technical manual. Toronto, Canada: Multi-Health Systems, Inc.

Bar-On, R. (2002). The Emotional Quotient Inventory (EQ-i): Technical manual. Toronto, Canada: Multi-Health Systems, Inc.

Bar-On, R. (2006). The Bar-On Model of Emotional Social Intelligence. Psicotherma, 18, 13-25.

Besterfield, H. Dale. (2003). Total Quality Management (3rd ed.). NJ: Pearson Education International: Prentice Hall, pp. 19-27, 35.

Bliss, E. Samuel. (2005). The effect of Emotional Intelligence on a Modern Organizational Leader's Ability to Make Effective Decisions. Retrieved January 18, 2013, from http://eqi.org/mgtpaper.htm

Bradberry, T., \& Greaves, J. (2003). Emotional intelligence quick book: Everything you need to know to put your EQ to work. San Diego, CA: Talent Smart Incorporation.

Bradford, D., \& Cohen, A. (1984). Managing for excellence: the guide to developing high performance in contemporary organizations. John Wiley, New York.

Champy, J. (2003). The Hidden Qualities of Great Leaders. Fast Company, 76, 135.

Cherniss, C. (2003). The business case for emotional intelligence. The Consortium for Research on Emotional Intelligence in Organizations. Retrieved April 8, 2012, from http://www.eiconsortium.org/research/business_case_for_ei.htm

Ciarrochi, J., Deane, F.P., \& Anderson S. (2002). Emotional intelligence moderates the relationship between stress and mental health. Personality and Individual Differences, 32(2), 197-209.

Cooper R., \& Sawaf A. (1997). Executive EQ: Emotional Intelligence in Business. London, Orion.

Deeter-Schmelz, D., Goebel, D., \& Norman, K. (2008). What are the characteristics of an effective sales manager? An exploratory study comparing salesperson and sales manager perspectives [Electronic version]. Journal of Personal Selling \& Sales Management, 28(1), 7-20. http://dx.doi.org/10.2753/PSS0885-3134280101

Douglas, C., Frink, D. D., \& Ferris, G. R. (2004). Emotional intelligence as a moderator of the relationship between conscientiousness and performance. Journal of Leadership \& Organizational Studies, 10(3), 2-13.

Dulewicz, V., \& Higgs, M. (2000). Emotional intelligence: The key to future successful corporate leadership [Electronic version]. Journal of General Management, 24(3), 1-14.

Dulewicz, V., \& Higgs, M. (2003). Leadership at the top: The need for emotional intelligence in organizations [Electronic version]. International Journal of Organizational Analysis, 11(3), 193-210. 
Freedman, Joshua, \& Everett, Todd. (2004). EQ at the Heart of Performance: The Business Case for Emotional Intelligence. Institute for Organizational Performance. (www.EQPerformance.com), p.5. Retrieved January 19, 2013, from http:/www.leabrovedani.com/wpcontent/uploads/The-Business-Case-for-Emotio-nal-Intelligence.pdf

Freshman, B., \& Rubino, L. (2002). Emotional Intelligence: A core competency for health care administrators [Electronic version]. The Health Care Manager, 24(3), 1-14.

Frigda, N.H. (1988). The laws of emotion. American Journal of Psychology, 43, 349-58. http://dx.doi.org/10.1037/0003-066X.43.5.349

George, J.M. (1995). Leader positive mood and group performance: The case of customer service. Journal of Applied Social Psychology, 25, 778-94. http://dx.doi.org/10.1111/j.1559-1816.1995.tb01775.x

George, J.M., \& Bettenhausen, K. (1990). Understanding pro-social behaviour, sales performance, and turnover: A group level analysis in a service context. Journal of Applied Psychology, 75, 698-709. http://dx.doi.org/10.1037/0021-9010.75.6.698

Goleman, D. (1995a). Emotional intelligence. New York: Bantam Books.

Goleman, D. (1998). Working with Emotional intelligence. NY: Bantam Books.

Goleman, D. (2001). Emotional intelligence: Issues in paradigm building. In C. Cherniss \& D. Goleman (Eds.), The emotionally intelligent workplace (pp. 13-26). Jossey-Bass: San Francisco.

Goleman, D. (2006). Social Intelligence: The New Science of Human Relationships. New York: Bantam Books.

Gowing, M. K. (2001). Measurement of individual emotional competence. In C. Cherniss, \& D. Goleman (Eds.), The emotionally intelligent workplace: How to select for, measure, and improve emotional intelligence in individuals, groups, and organizations (pp. 83-131). San Francisco, CA: Jossey-Bass.

Greenberger, D., \& Padesky Ch. (1995). Mind over mood. Change how you feel by changing the way you think. The Guilford Press: A division of Guilford Publications Inc., New York.

Gregersen, Hal, A. Morrison, \& J. Stewart Black. (1998). Developing Leaders for the Global Frontier. Sloan Management Review, Fall, 21-32.

Harms, P.D., \& Credé, M. (2010). Emotional Intelligence and Transformational and Transactional Leadership: A Meta-Analysis. Journal of Leadership \& $\quad$ Organizational Studies, $17(1)$, 5-17. http://dx.doi.org/10.1177/1548051809350894

Harvard Business Review. (2003, April). Breakthrough Ideas for Tomorrow's Business Agenda, 81(4), 92-8, 124.

Hofstede, Geert. (1997). Cultures and Organizations, Software of the Minds. New York: McGraw-Hill.

Ilangovan, Aarthi, Wesley A. Scroggins, \& Elizabeth J. Rozell. (2007). Managerial Perspectives on Emotional Intelligence Differences between India and the United States: The Development of Research Propositions. International Journal of Management, 24(3), 541-548.

Javidan, Mansour, \& Robert J. House. (2002). Leadership and Cultures around the World: Findings from GLOBE. Journal of Business, 37(1), 1-2.

Jones, G.R., \& George, J.M. (1998). The experience and evolution of trust: Implications for cooperation and teamwork. Academy of Management Review, 23, 531-46.

Kasapi, Z., \& Mihiotis, A. (2011). Management as applied to New Products Penetration in the Competitive Environment of Pharmaceutical Industry. Interdisciplinary Journal of Research in Business, 1(10), 73-85.

Kazazis, N. (2011). Pharmaceutical marketing. Stamoulis Editions (GR), pp. 89-93.

Law, K.S., Wong, C.S., \& Song L.J. (2004). The Construct and Criterion Validity of Emotional Intelligence and Its Potential Utility for Management Studies. Journal of Applied Psychology, 89(3), 483-496. http://dx.doi.org/10.1037/0021-9010.89.3.483

Leung, Alicia S.M. (2005). Emotional Intelligence or Emotional Blackmail: a Study of a Chinese Professional-Service Firm. International Journal of Cross Cultural Management, 5(2), 181-196.

Luthans, Fred. (2002). Organizational Behavior (9th ed.). McGraw- Hill/Irwin, pp. 581-582.

Mayer, J. D., Salovey, P., Caruso, D. R., \& Sitarenios, G. (2003). Measuring emotional intelligence with the MSCEIT V2.0. Emotion, 3, 97-105. http://dx.doi.org/10.1037/1528-3542.3.1.97

Mayer, J.D., \& Salovey, P. (1997). What is Emotional Intelligence? In P. Salovey \& D. J. Slutyer (Eds.), Emotional development and emotional intelligence: Implications for educators (pp. 3-31). NY: Basic Books. 
Mayer, J.D., Caruso, D.R., \& Salovey, P. (2000). Selecting a measure of emotional intelligence. In R. Bar-On \& J. Parker (Eds.), The Handbook of Emotional Intelligence. San Francisco: Jossey-Bass.

McClelland, D.C. (1998). Identifying competencies with behavioral event interviews. Psychological Science, 9(5), 331-340. http://dx.doi.org/10.1111/1467-9280.00065

McClelland, J. L. (1999). Cognitive modeling, connectionist: The MIT Encyclopedia of the Cognitive Science. Cambridge, MA: MIT Press, pp.137-139.

McGarvey Robert. (1997, October). Foul Play: Battling Hostilities in the Workplace. Entrepreneur Magazine.

McGuire John L., Horst Hasskarl, Gerd Bode, Ingrid Klingmann, \& Manuel Zahn. (2007). < Pharmaceuticals, General Survey> Ullmann's Encyclopedia of Chemical Technology. Wiley-VCH, Weinheim.

McKay M., Davis M., \& Fanning P. (2007). Thoughts and Feelings. Taking control of your moods and your life (3 ${ }^{\text {rd }}$ ed.). Oakland, USA. New Harbinger Publications, Inc.

Mihiotis A. (2005). Strategic Management, Vol. 4, Chapter 4. Hellenic Open University, University of Patras.

Mikolajczak, M, Petrides, K.V., Coumans, N., \& Luminet, O. (2009). The moderating effect of trait emotional intelligence on mood deterioration following laboratory-induced stress. International Journal of Clinical and Health Psychology, 9(3), 455-477.

Nelis, D., Quoidbach, J., Mikolajczak, M., \& Hansenne, M. (2009). Increasing emotional intelligence: (How) is it possible? Personality and Individual Differences, 47, 36-41. http://dx.doi.org/10.1016/j.paid.2009.01.046

O'Boyle Jr., E.H., Humphrey, R.H., Pollack, J.M., Hawver, T.H., \& Story, P.A. (2010). The relation between emotional intelligence and job performance: A meta-analysis. Journal of Organizational Behavior, 32(5), 788-818. http://dx.doi.org/10.1002/job.714

Pieterse, A., Knippenberg, D., \& Jinkel, W. (2011). Diversity in goal orientation, team reflexivity and team performance. Organizational Behaviour and Human Decision Processes, 114, 153-164.

Randall Grayson. (2010). Emotional Intelligence: A Summary. Retrieved February 6, from www.visionrealization.com

Robbins, Stephen P., \& Judge, Timothy A. (2012). Essentials of Organizational Behavior (11th ed.). Essex, United Kingdom: Pearson Education Limited.

Salovey, P., \& Mayer, J. D. (1990). Emotional intelligence [Electronic version]. Imagination, Cognition \& Personality, 9, 185-211. http://dx.doi.org/10.2190/DUGG-P24E-52WK-6CDG

Schwalbe, Kathy. (2001). Information Technology Project Management (3rd ed.). p. 319, p. 320, p. 348.

Sinclair, R.C. Mood. (1988). The effects of order of information acquisition and affective state on halo, accuracy, information retrieval, and evaluations. Journal of Organizational Behaviour and Human Decision Processes, 42, 22-46. http://dx.doi.org/10.1016/0749-5978(88)90018-0

Sinclair, R.C., \& Mark, M.M. (1992). The influence of mood state on judgement and action: Effects on persuasion, categorization, social justice, person perception, and judgmental accuracy. Hillsdale, NJ: Erlbaum, pp. 165-93.

Slaski, M., \& Cartwright, S. (2002). Health, performance, and emotional intelligence: An exploratory study of retail managers. Stress and Health, 18(2), 63-68. http://dx.doi.org/10.1002/smi.926

Sosik, John J., \& Megerian, Lara E. (1999). Understanding leader emotional intelligence and performance: The role of self-other agreement on transformational leadership perceptions. Group and Organization Management, 367-390. http://dx.doi.org/10.1177/1059601199243006

Sy, T., Tram, S., \& O'Hara, L.A. (2006). Relation of employee and manager emotional intelligence to job satisfaction and performance. Journal of Vocational Behavior, 68, 461-473. http://dx.doi.org/10.1016/j.jvb.2005.10.003

Trompenaars, Fons. (1993). Riding the Waves of Culture: Understanding Cultural Diversity in Business. London: Nicholas Brealey Publishing.

Walumbwa F., Mayer D., Wang P., \& Workman C. (2011). Linking ethical leadership to employee performance: The roles of leader member exchange, self-efficacy, and organizational identification. Organizational Behaviour and Human Decision Processes, 115, 204-213. http://dx.doi.org/10.1016/j.obhdp.2010.11.002

Weisinger, H. (1998). Emotional Intelligence at work. The untapped Edge for Success. San Francisco: Jossey-Bass Publishers Inc., pp.27-60. 